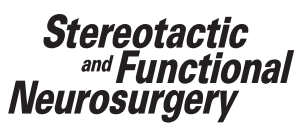

Stereotactic

Neurosurgery
Stereotact Funct Neurosurg 2011;89:263-274

DOI: $\underline{10.1159 / 000329357}$
Received: November 28, 2010

Accepted after revision: May 2, 2011

Published online: August 19, 2011

\title{
Spinal Cord Stimulation and Cerebral Hemodynamics: Updated Mechanism and Therapeutic Implications
}

\author{
Massimiliano Visocchi ${ }^{a}$ Giuseppe Maria Della Pepa ${ }^{a}$ Giuseppe Esposito ${ }^{a}$ \\ Tommaso Tufo $^{a}$ Wenchuan Zhang ${ }^{b}$ Shiting $\mathrm{Li}^{\mathrm{b}}$ Jun Zhong ${ }^{\mathrm{b}}$

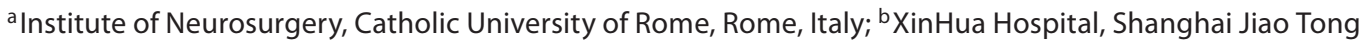 \\ University, Shanghai, China
}

\section{Key Words}

Spinal cord stimulation $\cdot$ Cerebral blood flow $\cdot$ Stroke $\cdot$

Brain injury · Vasospasm $\cdot$ Cerebral autoregulation .

Functional sympathectomy

\begin{abstract}
The effects of spinal cord stimulation (SCS) on cerebral blood flow (CBF) are well known based on experimental investigations, and its vasodilator effect on peripheral arteries is widely used in clinical settings in the treatment of peripheral vascular disease. Since Hosobuchi's [Appl Neurophysiol 1985;48:372-376] first observations on the effects of SCS on CBF were published 22 years ago, many advances have been made in understanding SCS-mediated effects on CBF. This paper reviews the main laboratory observations and analyzes the most significant neurophysiological theories on the SCS-mediated effect on CBF. Most significant experimental data have been discussed, with specific reference to possible mechanisms such as 'functional reversible sympathectomy', cerebral infarction and related ischemic edema, hemodynamic deterioration in experimental combined ischemictraumatic brain injury and cerebral vasospasm. The authors revised the published experiences in humans with hypoper-
\end{abstract}

fusion syndromes and 'adjuvant' locoregional CBF increase in chemotherapy of brain tumors. SCS represents a new perspective in challenging neurosurgical clinical fields such as cerebral ischemia and vasospasm, and seems promising as a new trend of functional neurosurgery in cerebrovascular diseases.

Copyright $\odot 2011$ S. Karger AG, Basel

\section{Introduction}

Spinal cord stimulation (SCS) is an accepted method of treatment of chronic refractory pain due to central and peripheral problems. The effects of cervical SCS on cerebral blood flow $(\mathrm{CBF})$ are well known based on experimental investigations, and its vasodilator effect on peripheral arteries is widely used in clinical settings in the treatment of peripheral vascular disease [1-3]. An increase in CBF, both in animals and humans, has been demonstrated so far, and different theories have been tried to explain these observations. In particular, the role of SCS has been explored as a novel therapeutic option in the management of stroke and several low-perfusion syndromes. More recently, cervical SCS effects on cerebral

\section{KARGER}

Fax +41613061234 E-Mail karger@karger.ch www.karger.com
(C) 2011 S. Karger AG, Basel

1011-6125/11/0895-0274\$38.00/0

Accessible online at:

www.karger.com/sfn
Giuseppe Maria Della Pepa, MD

Institute of Neurosurgery

Catholic University School of Medicine, Largo A. Gemelli, 8

IT-00168 Rome (Italy)

Tel. +39 339455 9769, E-Mail gdellapepa@hotmail.com 
vasculature have been specifically proposed for the management of subarachnoid hemorrhage (SAH) and related arterial vasospasm $[4,5]$.

Although many claims of circulatory improvements in these circumstances are provided in the literature, no clinical application has yet been clearly established. A complete understanding of physiological and anatomic correlation between CBF modulation and SCS still remains unclear. This paper reviews with a wide-ranging approach the entire SCS-cerebral hemodynamic issue, analyzing the main laboratory and clinical observations that have been published up to now, discussing the most relevant scientific hypothesis and focusing on possible future therapeutic and experimental applications of SCS in the regulation of human $\mathrm{CBF}$.

\section{Basic Observations in the Laboratories}

In 1984, Reis [6] showed a reduction in the intracranial vasomotor control together with an increase in the $\mathrm{CBF}$ following electrical stimulation of the medullar reticular formation.

The initial studies on experimental animals are very intriguing. In 1987, Garcia-March et al. [7] reported CBF changes induced by SCS in animals and such evidence was confirmed by studies from our laboratories [8]. In the former study, dogs were used to determine hemodynamic changes in the carotid territory and goats were used to evaluate hemispheric blood flow. The results showed an average increase of $\mathrm{CBF}$ at the common and internal carotid level of more than $60 \%$ and an increase of CBF of more than $50 \%$. These changes occurred during the first 15 min of stimulation [9]. In the latter study, rabbits were stimulated at the cervical level: an increase in CBF was detected in more than half of the samples, and significant CBF changes were evident from the 5th min of SCS, with CBF changes ranging between 20 and $100 \%$. Bilateral or unilateral changes were independent from the electrode site.

One year later, Isono et al. [10] confirmed an increase in CBF during cervical SCS in cats up to $140 \%$, lasting for 15 min after the end of SCS. In 2000, a paper by Sagher and Huang [11] showed an increase in cortical CBF of about $83 \%$. This was not accompanied by a significant increase in systemic blood pressure. The authors observed that stimulation of the upper cervical cord was more effective than that of the lower cervical cord. More recently, in 2004, Zhong et al. [12] underlined the role of stimulating parameters in increasing $\mathrm{CBF}$ during SCS.
They concluded that 'the magnitude of the response varied in a dose-dependent fashion with the stimulation amplitude although the magnitude of this effect diminished to approximately $50 \%$ over the baseline after 10 minutes'.

Experimental and clinical studies on humans and animal models investigating the mechanisms involved in SCS are summarized in table 1.

\section{Pioneer Observations in Humans}

In 1985, Hosobuchi [13] was the first to study the effects of SCS on cerebral hemodynamics in humans. He used a single-photon emission computed tomography (SPECT) technique to investigate CBF changes in 10 patients treated with SCS for chronic intractable pain. Cervical stimulation was observed to produce a significant rise in hemispheric CBF ipsilaterally to the induced paresthesiae, suggesting that the alteration in CBF was not related to the increased cerebral metabolic rate resulting from the afferent volley produced by the artificial stimulation of the spinal cord.

In 1986, some experimental studies published by some of the authors of the present paper focused on the effects of spinal cord epidural electrodes at different segmental levels with both transcranial Doppler sonography (TCD) and SPECT [14, 16, 17]. It was observed that SCS can produce either an increase in $\mathrm{CBF}$, a reduction, or no effect. A reduction of $\mathrm{CBF}$ is very rare and occurs in a more caudal electrode location (thoracic SCS), while cervical stimulation produces more frequently an increase in $\mathrm{CBF}$ $[1,17,18]$.

Mazzone et al. $[19,20]$ were the first to introduce the concept of 'redistribution of CBF' rather than an absolute change in CBF during SCS. SCS appears to influence intracerebral blood flow distribution mainly in the anterior regions, rather than giving an absolute change in the blood flow. The authors suggested a possible neurogenic mechanism mediated by thalamus-cortical projections.

\section{SCS and CBF: The Possible Mechanisms (Studies in Animals and Humans)}

SCS has been shown to augment CBF and speculated to protect the brain from focal ischemia in a large series of experiences in both animals and humans. However, there is not yet an ultimate scientific explanation, and a clear understanding of the mechanisms elicited by SCS is still lacking. Different hypotheses have been reported in 
Table 1. Experimental and clinical studies in humans and animal models investigating the mechanisms involved in SCS effects on CBF

\begin{tabular}{|c|c|c|c|}
\hline $\begin{array}{l}\text { Reference } \\
\text { (first author) }\end{array}$ & Observation method & $\begin{array}{l}\text { Site of stimulating } \\
\text { electrode (models) }\end{array}$ & Hemodynamic findings \\
\hline $\begin{array}{l}\text { Reis } \\
1984[6]\end{array}$ & $\begin{array}{l}\text { measurement of plasma } \\
\text { catecholamines and } \\
\text { vasopressin }\end{array}$ & $\begin{array}{l}\text { rostral ventrolateral } \\
\text { medullary reticular } \\
\text { formation (rats) }\end{array}$ & $\begin{array}{l}\text { electrical stimulation induces reduction in the intracranial } \\
\text { vasomotor control together with an increase in CBF }\end{array}$ \\
\hline $\begin{array}{l}\text { Hosobuchi } \\
1985[13]\end{array}$ & SPECT $\left({ }^{133} \mathrm{Xe}\right)$ & $\begin{array}{l}\text { cervical/thoracic } \\
\text { (humans) }\end{array}$ & $\begin{array}{l}\text { indomethacin blocks CBF effects; atropine does not affect } \\
\text { CBF effects }\end{array}$ \\
\hline $\begin{array}{l}\text { Meglio } \\
1986[23]\end{array}$ & TCD, SPECT & $\begin{array}{l}\text { cervical/thoracic } \\
\text { (humans) }\end{array}$ & $\begin{array}{l}\text { functional sympathectomy during SCS (parasympathetic } \\
\text { activation and blockade) }\end{array}$ \\
\hline $\begin{array}{l}\text { Garcia-March } \\
1989[9]\end{array}$ & $\begin{array}{l}\text { electromagnetic carotid } \\
\text { flowmetry; }{ }^{131} \text { I antipyrine } \\
\text { brain scintigraph }\end{array}$ & $\begin{array}{l}\text { upper cervical } \\
\text { (dogs/goats) }\end{array}$ & $\begin{array}{l}\text { increase of CBF at the common and internal carotid level } \\
\text { of more than } 60 \% \text { and an increase of CBF of more than } \\
50 \%\end{array}$ \\
\hline $\begin{array}{l}\text { Linderoth } \\
1991,1995[15,16]\end{array}$ & $\begin{array}{l}\text { limb laser Doppler } \\
\text { flowmetry }\end{array}$ & $\begin{array}{l}\text { cervical/thoracic } \\
\text { (rats) }\end{array}$ & inhibition of sympathetic activity \\
\hline $\begin{array}{l}\text { Visocchi } \\
1992[32]\end{array}$ & $\begin{array}{l}\text { TCD; OBF system of } \\
\text { Langhans }\end{array}$ & $\begin{array}{l}\text { cervical/dorsal } \\
\text { (humans) }\end{array}$ & $\begin{array}{l}\text { SCS changes CBF and OBF at the same time with the } \\
\text { same sign (same autoregulatory mechanisms?) }\end{array}$ \\
\hline $\begin{array}{l}\text { Visocchi } \\
1992[24]\end{array}$ & $\begin{array}{l}\text { electromagnetic } \\
\text { flowmetry; CW Doppler }\end{array}$ & cervical (rabbits) & reduction of sympathetic excitability \\
\hline $\begin{array}{l}\text { Isono } \\
1995[10]\end{array}$ & $\begin{array}{l}\text { hydrogen clearance } \\
\text { method }\end{array}$ & cervical (cats) & no CBF effects during SCS after lesion of dorsal column \\
\hline $\begin{array}{l}\text { Myklebust } \\
1995[25]\end{array}$ & $\begin{array}{l}\text { limb radioactive } \\
\text { microsphere clearance }\end{array}$ & $\begin{array}{l}\text { dorsal/lumbar } \\
\text { (monkey) }\end{array}$ & sympathetic inactivation during SCS ( $\downarrow$ NE level) \\
\hline $\begin{array}{l}\text { Visocchi } \\
1996[33]\end{array}$ & TCD & cervical (humans) & $\begin{array}{l}\text { SCS and } \mathrm{CO}_{2} \text { interact with mechanisms of } \\
\text { regulation of } \mathrm{CBF} \text { in a competitive way }\end{array}$ \\
\hline $\begin{array}{l}\text { Sagher } \\
2000,2003,2006 \\
{[11,37,62]}\end{array}$ & laser Doppler flowmetry & $\begin{array}{l}\text { higher cervical; } \\
\text { lower cervical (rats) }\end{array}$ & $\begin{array}{l}\text { increase in cortical CBF of } 83 \pm 11 \% \text {; stimulation of } \\
\text { the upper cervical cord was more effective than was that } \\
\text { of the lower cervical cord (changes in CBF were } \\
\text { significantly attenuated after spinal cord transaction and } \\
\text { by sympathetic blockers) }\end{array}$ \\
\hline $\begin{array}{l}\text { Patel } \\
2003,2004[26,27]\end{array}$ & $\begin{array}{l}{ }^{14} \mathrm{C} \text {-inosine } \\
\text { monophosphate } \\
\text { radiotracer studies }\end{array}$ & cervical (rats) & $\begin{array}{l}\text { effects of SCS involve central influences rather than } \\
\text { cervical sympathetic outflow (spinalization affects CBF } \\
\text { increase during SCS) }\end{array}$ \\
\hline $\begin{array}{l}\text { Zhong } \\
2004[12]\end{array}$ & laser Doppler flowmetry & cervical (rats) & $\begin{array}{l}\text { magnitude of the response varied in a dose-dependent } \\
\text { fashion with the stimulation amplitude }\end{array}$ \\
\hline $\begin{array}{l}\mathrm{Wu} \\
2007[29]\end{array}$ & laser Doppler flowmetry & cervical (rats) & $\begin{array}{l}\text { blockage of } \mathrm{GCRP}_{8-37} \text { receptor reduces } \mathrm{CBF} \text { and CVR } \\
\text { effects }\end{array}$ \\
\hline $\begin{array}{l}\text { Yang } \\
2008[30]\end{array}$ & laser Doppler flowmetry & cervical (rats) & $\begin{array}{l}\text { TRPV1 agonists block CBF effects; cerebral but not spinal } \\
\text { TRPV1 is involved in cSCS-induced cerebral } \\
\text { vasodilatation }\end{array}$ \\
\hline $\begin{array}{l}\mathrm{Wu} \\
2008[31]\end{array}$ & laser Doppler flowmetry & cervical (rats) & $\begin{array}{l}\text { inhibition of extracellular signal-regulated kinase and } \\
\text { protein kinase B reduces SCS-induced } \\
\text { vasodilatation }\end{array}$ \\
\hline $\begin{array}{l}\text { Ter Laan } \\
2010[21]\end{array}$ & TCD & cervical (humans) & $\begin{array}{l}\text { cervical electrical neurostimulation (TENS) is not able to } \\
\text { provide the same effects produced by SCS on human CBF }\end{array}$ \\
\hline
\end{tabular}

CW Doppler $=$ Continuous-wave Doppler; $\mathrm{NE}=$ norepinephrine; OBF = ocular blood flow. 


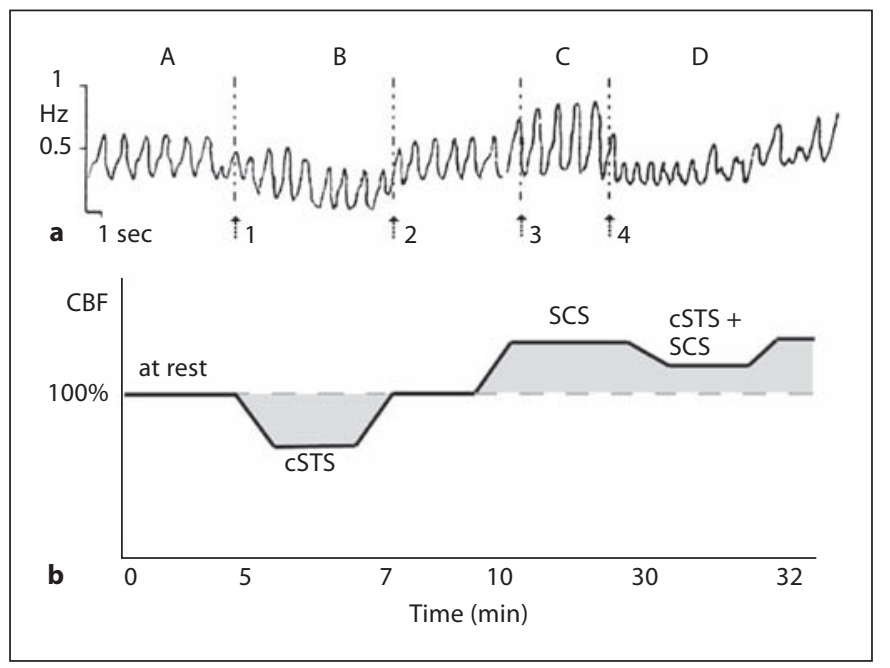

Fig. 1. SCS effects on sympathetic excitability. a CBF of the internal carotid arteries was measured in 4 rabbits by means of a Doppler device (Multi-Dop ${ }^{\circledR}$ X 2 DWL; Esaote) and electromagnetic flowmeter (Transonic Model T 106; Ithaca, N.Y., USA). The study was carried out: (1) in basal conditions, (2) during sympathetic trunk stimulation (STS) (10 V, 10 cycles/s, $0.5 \mathrm{~ms}$ duration, for $1 \mathrm{~min})$ at the neck, (3) during SCS (210 $\mu$ s duration, 80 cycles/s, with intensity $2 / 3$ of the motor threshold, applied for $20 \mathrm{~min}$ ), and (4) during simultaneous SCS and sympathetic trunk stimulation. In $\mathrm{A}, \mathrm{CBF}$ measurement at rest; diastolic velocity is $0.3 \mathrm{kHz}$. In $\mathrm{B}, \mathrm{CBF}$ measurement during STS; the diastolic flow is decreased almost to zero. In $\mathrm{C}, \mathrm{CBF}$ measurement during SCS; the diastolic flow is slightly increased compared to rest condition. In $\mathrm{D}, \mathrm{CBF}$ measurement during simultaneous SCS and STS stimulation; the diastolic flow is slightly decreased. If we compare the decrease of diastolic flow in $B$ and D, we conclude that SCS counteracts the effect of STS. $\mathbf{b}$ Schematic representation of the experiment [modified from 23-51].

the literature so far. From a review of the literature, more than a single mechanism seems to be responsible for $\mathrm{CBF}$ augmentation with SCS. Experimental and clinical data support the idea that the autonomic nervous system might be the major mechanism elicited by cervical SCS, although recent studies underline how the release of local humoral factors by the cerebral vasculature might also play a significant role in determining the SCS effect on cerebral hemodynamics.

Recently, a paper by Ter Lan et al. [21] demonstrated that the effects shown by SCS on CBF cannot be obtained by transcutaneous electrical neurostimulation at the cervical level.

\section{Role of the Autonomic System}

A reduction of sympathetic outflow during SCS has been demonstrated by a series of studies. Such so-called 'reversible functional sympathectomy' can, at least partially, account as one of the possible mechanisms put in play by SCS to produce such effects on cerebral hemodynamics $[10,22]$. Linderoth et al. [16] have studied SCS-induced neurotransmitter release in the spinal dorsal horn and the periaqueductal gray substance of rats and cats, demonstrating that SCS-induced peripheral vasodilatation was abolished by bilateral sympathectomy in rats and that peripheral sympathetic activity might be suppressed by SCS applied at the T2 level in cats. Personal studies aimed at investigating sympathetic balance during experimental SCS confirmed the functional reversible sympathectomy in mediating CBF changes by analyzing both SCS and the sympathetic trunk stimulation effects on rabbit's CBF. A reduction of $\mathrm{CBF}$ was evident in every case soon after starting sympathetic trunk stimulation, showing that a decrease of cervical sympathetic excitability occurs as a consequence of SCS (fig. 1). This indicates that SCS induces a decrease in sympathetic excitability [23-25].

Myklebust et al. [25] found norepinephrine levels markedly affected during SCS, confirming a sympathetic inactivation secondary to neurostimulation. More recently, Patel et al. $[26,27]$ pointed out that sympathetic tone effects on CBF are mediated primarily by $\alpha_{1}$-adrenergic receptors. They observed that an increase in CBF with SCS is in direct relation with specific sympathetic receptors. Their experiments from 2003 to 2004 demonstrated that either sympathetic ganglion blocker or $\alpha_{1}$-adrenergic receptor blocker can abolish the response to SCS, but the same result does not happen with $\alpha_{2}$ - or $\beta$-adrenergic receptor blockers. In particular, they focused on two alternative pathways in CBF alterations induced by SCS in rats: one pathway involves direct modulation of sympathetic outflow (superior cervical ganglion removal) and the other operates through central vasomotor influence (after spinalization at the cervico-medullary junction) [27].

Very intriguingly, one of the authors of the present paper, in 2004, investigated the effects of SCS on sympathetic and parasympathetic innervations in mediating the $\mathrm{CBF}$ changes in rats by inducing selective resection of the nasociliary and post-ganglionic parasympathetic nerve fibers or alternatively bilateral resection of the superior cervical ganglion [12]. In such an experimental setting the authors observed that surgical interruption of both the parasympathetic and sympathetic pathways counteract the SCS-induced CBF increase (fig. 2).

\section{Role of Specific Spinal Cord Pathways}

Several works analyzed how spinal cord integrity deals with the SCS interferences on CBF. The most significant 


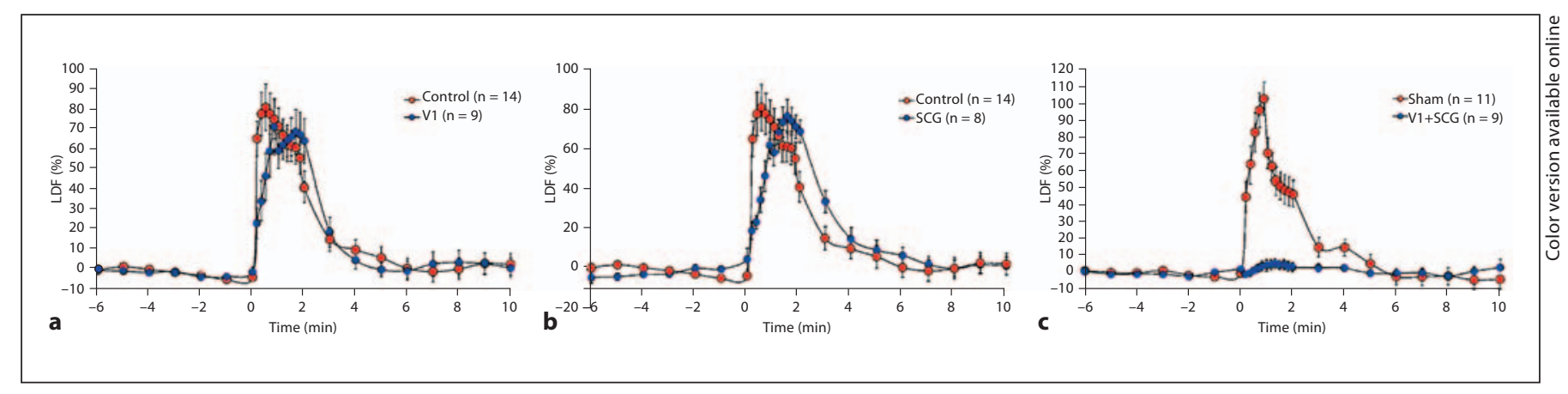

Fig. 2. Effects of SCS on sympathetic and parasympathetic innervations in mediating the CBF changes. The animals (rabbits) were divided into 5 groups undergoing SCS and laser Doppler flowmeter (LDF) recordings. a Control group: the animal underwent SCS and LDF recordings without any lesion of the nerve fibers and ganglia. V1 group: the animal underwent bilateral resection of the nasociliary and post-ganglionic parasympathetic nerve fibers. b SCG group: the animal underwent bilateral resection of superior cervical ganglion (SCG). c V1+SCG group: the animal un- derwent both surgeries of V1 and SCG groups. Sham group: the animals underwent the carotid manipulation with blunt-tipped forceps and the dissection of nasociliary and post-ganglionic parasympathetic nerve fibers. No statistical differences in $\mathrm{CBF}$ changes were found during SCS between the NC, SCG and sham groups. The effects of SCS on CBF were completely abolished in the NC+SCG group. The surgical interruption of both the parasympathetic and sympathetic pathways counteracts the SCS-induced CBF increase [modified from 12]. experiences have been published by Isono et al. [10] and Patel et al. [27]. Isono et al. [10] observed that the ability of SCS to increase CBF is peculiar to high cervical cord stimulation with moderately low frequencies and that no hemodynamic effect occurs during SCS when the dorsal column is sectioned at the medullo-cervical junction, confirming the role of specific spinal cord pathways in determining the increase of CBF during SCS. Patel et al. [27] reported that SCS-induced changes in CBF were completely attenuated by spinalization, suggesting that the mechanisms underlying the effects of SCS involve central influences rather than cervical sympathetic outflow.

\section{Role of Humoral Factors}

Hosobuchi [13] in his pioneer observations in humans had already noticed a persistent elevation of CBF also after interruption of the stimulation. He suggested that this phenomenon could be explained by the involvement of humoral factors. In particular, he observed that indomethacin was able to partially block the effect of SCS on $\mathrm{CBF}$, while atropine did not affect the results. Other possible factors involved and proposed include substance $\mathrm{P}$, vasoactive intestinal polypeptide and calcitonin gene-related peptide [28].

Recent experimental studies suggest that SCS also produces the release of important less known neurogenic vasodilators. Wu et al. [29] concluded that SCS antidromically activates the transient receptor potential vanilloid type 1 (TRPV1) containing sensory fibers and produces the release of calcitonin gene-related peptide that is known to be a powerful mediator of vascular dilatation. Yang et al. [30] further explored the role of these mediators suggesting that cerebral but not spinal TRPV1 is involved in SCS-induced cerebral vasodilatation. Again, Wu et al. [31] identified two new molecular pathways in the spinal cord, extracellular signal-regulated kinase and protein kinase B, that are involved in SCS-induced vasodilatation.

\section{Role of Autoregulation}

Further study of the possible mechanisms involved in cervical SCS in TCD-assessed responsive patients were performed by using the $\mathrm{CO}_{2}$ autoregulation test [18] The TCD patterns were evaluated and compared during progressive hypercapnia, both in basal conditions and during SCS. Increase in $\mathrm{CO}_{2}$ produces vasodilatation, which is detected by TCD with an increase in blood velocity and a decrease in resistance parameters, whereas during SCS, we demonstrated a reduction of the response to $\mathrm{CO}_{2}$ (fig. 3) $[32,33]$. A possible explanation of such a phenomenon is that SCS and $\mathrm{CO}_{2}$ interact with the mechanism of regulation of $\mathrm{CBF}$ in a competitive way. They may act competitively on the same target. If so, we could extrapolate that the resistance arterioles are at least one of the targets of SCS in producing its cerebrovascular effect. 
Fig. 3. $\mathrm{CO}_{2}$-induced variations of $\mathrm{CBF}$ detected by TCD. The TCD patterns were evaluated and compared during progressive hypercapnia in 3 human samples, both in basal conditions and during SCS. Hypercapnia was initially induced by rebreathing of a mixture containing $7 \% \mathrm{CO}_{2}$ and $93 \% \mathrm{O}_{2}$. The $\mathrm{CO}_{2}$ concentrations were continuously monitored by mass spectrometry. The variables of the respiratory model were evaluated by a pneumotachograph. Increase in $\mathrm{CO}_{2}$ produces vasodilatation, which is detected by TCD with an increase in blood velocity and a decrease in resistance parameters. By repeating the same study in the same patients during SCS, we demonstrated a reduction of the response to $\mathrm{CO}_{2}$. The waveforms of $\mathrm{CBF}$ velocity in basal conditions (a) and during SCS (b) during a progressive increase of similar $\mathrm{CO}_{2}$ concentrations show less $\mathrm{CO}_{2}$-induced vasodilatation during SCS. Spotted areas: difference between waveform from basal to end of experiment [modified from 32].

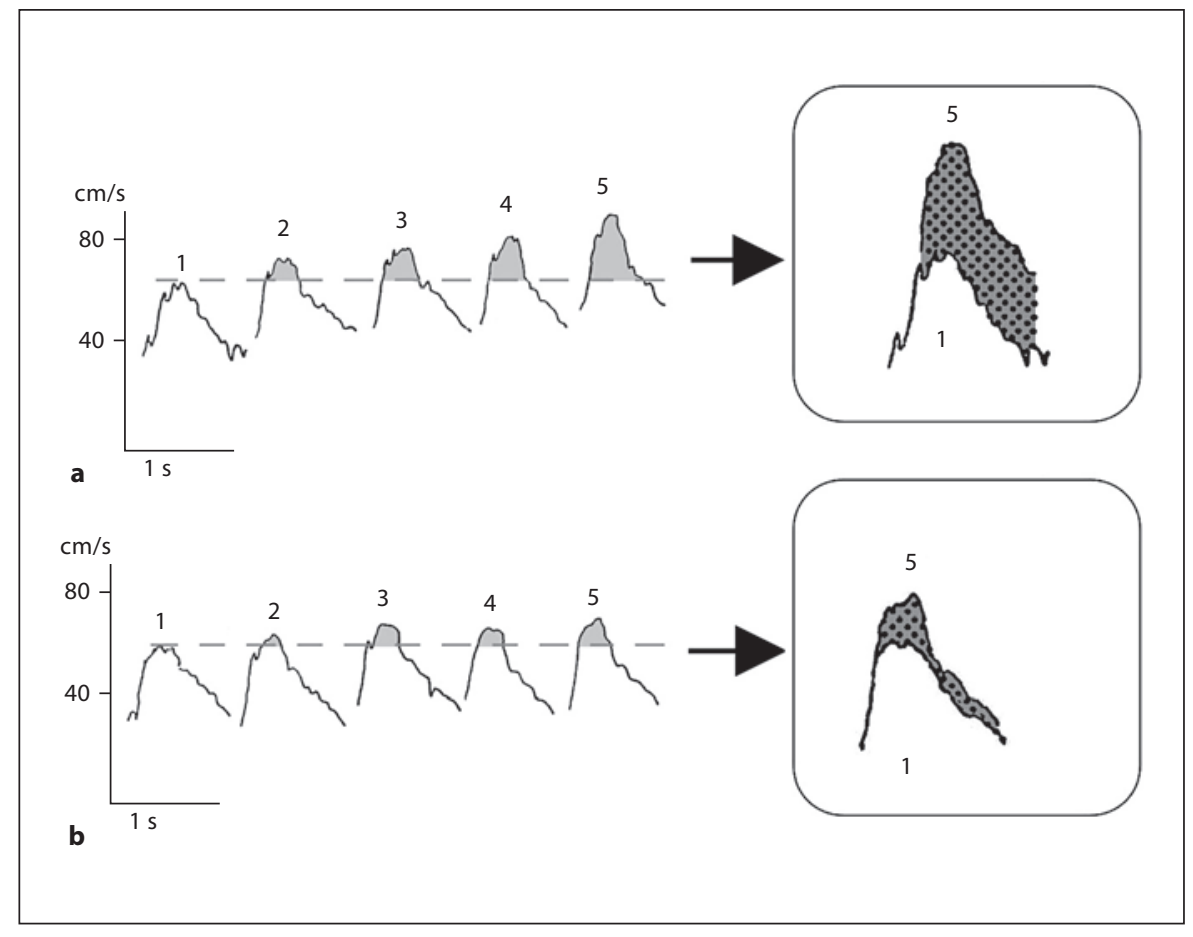

\section{Possible Therapeutic Implications}

Several experimental trials have been undertaken in order to specifically assess the utility of SCS in the clinical field of low-perfusion syndromes such as ischemic stroke, traumatic ischemic brain injury, $\mathrm{SAH}$ and related arterial vasospasm. The most significant experiences are summarized in table 2 .

\section{Experimental Trials}

Stroke

In 1989, Matsui and Hosobuchi [34] reported the effects of SCS on experimental stroke. They used a cat middle cerebral artery (MCA) occlusion model and compared data between a control group with occlusion of the MCA only, and a group undergoing cervical SCS. They observed that cervical SCS prolonged the survival rate within $24 \mathrm{~h}$ after ischemia and that infarct size was significantly different among the surviving cats of the two groups, demonstrating that cerebral SCS prevents the progression of brain infarction [34]. Two years later, Gonzalez-Darder and Canadas-Rodriguez [35] showed that cervical SCS significantly reduces brain edema in diffuse cerebral ischemia achieved by temporary occlusion of both carotid arteries followed by a reperfusion period. Such protection from ischemia-induced edema occurs when stimulation starts $1 \mathrm{~h}$ before ischemia and immediately after ischemia, indicating that the effect is more prominent using stimulation during the reperfusion period. The mechanism mediating such an effect of SCS could be a global increase in CBF, limiting the extension and intensity of ischemic or metabolic changes in cerebral tissue protecting the brain against ischemia or the activation of systems changing the intracranial vascular response.

A similar experience was published by Broseta et al. [36] in 1994. They observed the results of cervical SCS in three groups of rabbits with different stroke models (bilateral carotid ligation, unilateral microcoagulation of the MCA and microcoagulation of the vertebral artery). Improvement of $\mathrm{CBF}$ ranging from 27 to $32 \%$ was recorded a week after ischemia in the lesion area.

More recently, Sagher et al. [37] used the MCA occlusion model in rats and observed that SCS reduced stroke volume. The authors concluded: 'a strategy performing SCS for the prevention of critical ischemia is feasible and may have potential for the treatment and prevention of the stroke'. 
Table 2. Experimental studies on the effects of SCS on cerebral low-perfusion syndromes

\begin{tabular}{|c|c|c|c|c|}
\hline $\begin{array}{l}\text { Reference } \\
\text { (first author) }\end{array}$ & Experimental model & $\begin{array}{l}\text { Stimulating } \\
\text { electrode site }\end{array}$ & Effect recording & Observations \\
\hline $\begin{array}{l}\text { Matsui } \\
1989[49]\end{array}$ & experimental stroke (MCAO in cats) & cervical & $\begin{array}{l}\text { TTC method and } \\
\text { measured by computer } \\
\text { technique (PDP-11/23) }\end{array}$ & $\begin{array}{l}\uparrow \text { survival rate; prevent } \\
\text { progression of brain } \\
\text { infarction }\end{array}$ \\
\hline $\begin{array}{l}\text { Gonzales-Darder } \\
1991[35]\end{array}$ & $\begin{array}{l}\text { experimental stroke (both carotid } \\
\text { arteries occlusion in rats) }\end{array}$ & cervical & $\begin{array}{l}\text { microgravimetric tech- } \\
\text { nique in a bromoben- } \\
\text { zene-petroleum column }\end{array}$ & $\begin{array}{l}\text { reduction of ischemic brain } \\
\text { edema }\end{array}$ \\
\hline $\begin{array}{l}\text { Broseta } \\
1994[36]\end{array}$ & $\begin{array}{l}\text { experimental stroke in three different } \\
\text { ischemic settings (MCAO; bilateral } \\
\text { carotid artery occlusion; vertebral } \\
\text { artery occlusion in rabbits) }\end{array}$ & cervical & laser Doppler & $\begin{array}{l}\text { improving CBF by } 27 \% \\
\text { (hemisphere) and } 32 \% \\
\text { (posterior fossa) after } 1 \\
\text { week from obstruction }\end{array}$ \\
\hline $\begin{array}{l}\text { Visocchi } \\
2001[43]\end{array}$ & $\begin{array}{l}\text { experimental brain injury and stroke } \\
\text { both carotid arteries occlusion in } \\
\text { rabbits (ligature of both carotid arteries, } \\
+ \text { right hemispheric craniectomy and } \\
3 \text { h of mechanical injury ( } 200 \mathrm{mg} \text { ) over } \\
\text { the dura) }\end{array}$ & cervical & MRI; NIRS & $\begin{array}{l}\text { preventing secondary } \\
\text { ischemic damage in } \\
\text { combined traumatic- } \\
\text { ischemic brain injury }\end{array}$ \\
\hline $\begin{array}{l}\text { Sagher } \\
2003 \text { [37] }\end{array}$ & experimental stroke (MCAO in rats) & cervical & $\begin{array}{l}\text { laser Doppler and } \\
\text { radiotracer clearance }\end{array}$ & $\begin{array}{l}\text { reduction of stroke } \\
\text { volume }\end{array}$ \\
\hline $\begin{array}{l}\text { Visocchi } \\
1994,1996,2001 \\
{[41,42,64]}\end{array}$ & $\begin{array}{l}\text { experimental SAH 'early spasm' } \\
\text { in rabbits }\end{array}$ & cervical & $\begin{array}{l}\text { angiography; electro- } \\
\text { magnetic flowmetry }\end{array}$ & prevention of vasospasm \\
\hline $\begin{array}{l}\text { Ebel } \\
2001[44]\end{array}$ & $\begin{array}{l}\text { experimental SAH 'early spasm' } \\
\text { in rats }\end{array}$ & cervical & $\begin{array}{l}{ }^{99 m} \mathrm{Tc}-\mathrm{HMPAO} \\
\text { investigation }\end{array}$ & $\begin{array}{l}\text { improving cerebral and } \\
\text { cerebellar blood flow }\end{array}$ \\
\hline $\begin{array}{l}\text { Gurelik } \\
2005[46]\end{array}$ & $\begin{array}{l}\text { experimental cerebral vasospasm } \\
\text { in rats }\end{array}$ & cervical & $\begin{array}{l}\text { laser Doppler } \\
\text { flowmetry }\end{array}$ & $\begin{array}{l}\text { improving latencies and } \\
\text { amplitudes of MEP }\end{array}$ \\
\hline $\begin{array}{l}\text { Karadag } \\
2005[47]\end{array}$ & $\begin{array}{l}\text { experimental cerebral vasospasm } \\
\text { in rabbits }\end{array}$ & cervical & $\begin{array}{l}\text { laser Doppler } \\
\text { flowmetry }\end{array}$ & $\begin{array}{l}\text { increasing cerebral cortical } \\
\text { blood flow }\end{array}$ \\
\hline $\begin{array}{l}\text { Lee } \\
2008[65]\end{array}$ & $\begin{array}{l}\text { experimental cerebral chronic } \\
\text { vasospasm in rats after SAH }\end{array}$ & cervical & $\begin{array}{l}\text { sectional studies of } \\
\text { the BA and LDF }\end{array}$ & $\begin{array}{l}\text { increase in the diameter } \\
\text { (cross-sectional area) of BA } \\
\text { and increase in cortical } \\
\text { blood flow }\end{array}$ \\
\hline
\end{tabular}

MCAO = Middle cerebral artery occlusion model; MEP = motor-evoked potentials; PDP-11/23 = type of computer processor card; ${ }^{99} \mathrm{~m}$ Tc-HMPAO = flow tracer; TTC = triphenyltetrazolium chloride solution (histochemical staining; TTC method); BA = basilar artery; LDF = laser Doppler flowmetry.

Traumatic-Ischemic Brain Damage

Exploring the issue of traumatic-ischemic brain damage, in 2001 the authors of the present paper [38] evaluated the possible protective effect of SCS in a specific animal setting reproducing a combined ischemictraumatic brain injury. A setting with bilateral carotid ligation plus mechanical injury over the dura was used in 20 rabbits. None of the animals undergoing simulta- neous SCS showed a lesion pattern that extended far from the local mechanical injury, suggesting a 'preventing' effect of SCS on the secondary damage associated with ischemic and traumatic brain injury. Moreover, near-infrared spectroscopy (NIRS) showed changes consistent with $\mathrm{CBF}$ salvage in the brain area under brain injury [8]. 
SAH and Cerebral Vasospasm

It seems quite clear that morphologic changes occur in the cerebral vessels after SAH, and the inflammatory response and local chemical agents are responsible for the induction of vasospasm. The sympathetic system also plays an important role in the pathogenesis of this process [39]. Interestingly, Naredi et al. [40] found increased sympathetic activity in patients with non-traumatic SAH.

From 1994 to 2001, studies from our laboratories were performed on the effects of cervical SCS on experimental cerebral early spasm after SAH $[15,28,37,41-43]$. In particular, cervical SCS was observed to be able to prevent early spasm in a 'protective' fashion when stimulation was started before SAH. TCD provides an easy and reliable indication of correspondent CBF modifications both in homeostatic conditions (augmentation CBF with increase in TCD velocities along with a reduction of resistive index) and during vasospasm (decrease in CBF with increase in TCD velocities as well as an increase of resistive index) [14].

These pioneer observations were followed by Ebel et al. $[44,45]$, who evaluated the effect of cervical SCS on CBF in rats with $\mathrm{SAH}$ demonstrating an enhancement in cerebral and cerebellar blood flow. Gurelik et al. [46] and Karadag et al. [47] first demonstrated an improvement mediated by SCS in latencies and amplitudes of motorevoked potentials along with an improvement in cortical blood flow in SAH rabbits.

These experimental settings demonstrated that SCS at cervical levels may modulate sympathetic activity, essentially constituting a functional, temporary sympathectomy, and preventing cerebral arteries from vasoconstriction after SAH.

\section{Clinical Trials on Hypoperfusion Syndromes in Humans}

These preliminary observations led to a great deal of interest in their possible clinical applications on humans. The most significant studies are reported in table 3 and deal mostly with persistent vegetative-state patients. The observations made in comatose patients are complex because of the variability of the clinical pattern, the extensive damage and the remarkable preexisting functional alterations. Up to now, there is still no definitive data showing a correlation between clinical improvement and SCS effects on CBF.

The first attempt was performed in 1989 by Kanno et al. [48] who reported 23 patients in vegetative states treated with cervical SCS. A good clinical improvement was evident in 8 patients. A decrease as well as an increase of
CBF was shown, but there was no a clear correlation with the clinical outcome.

Matsui et al. [49] also made some preliminary observations in patients with impaired consciousness. An increase in CBF following SCS was observed in some patients, although there was no clear correlation with the clinical outcome.

Following these clinical and experimental observations on comatose patients, Hosobuchi [50] first used cervical SCS specifically for patients with symptomatic cerebral ischemia caused by advanced arteriosclerotic vascular disease or bilateral carotid occlusive disease considered not amenable to conventional surgery because 'of an unacceptably high surgical risk or because their symptoms were not severe enough to justify the risk of the procedure'. Hosobuchi focused both on hemodynamic and clinical changes: cervical SCS alleviated the symptoms of ischemia, with an increase, though not constant, in alertness, retention, speech, emotional lability and performance in skilled acts. This was associated with an increase in terms of CBF.

In 1994, one of the authors' observations was published concerning a single case of a 64-year-old patient who developed severe spastic hemiparesis and dysphasia following a left parietotemporal chronic ischemic stroke [51]. Clinical and neurophysiological studies (surface polyelectromyography) were performed along with TCD examination before and after 7 days of SCS. An improvement of clinico-neurophysiological findings was observed as well as an increase of CBF velocity. The evidence of improvement of dysphasia suggested the primary role of CBF changes as an effect of SCS [52].

In the same year, Broseta et al. [36] published the results of SCS performed on 10 patients presenting with various cerebral low-perfusion syndromes. Though not constant, an increase of alertness, retention, speech, emotional lability and performance in skilled acts was achieved. No MRI changes were observed, although SPECT readings showed an 'increase in blood flow in the penumbral perilesional area'.

Finally, authors published a personal series concerning 18 patients harboring a CT/MRI cerebral lesion pattern dealing with a vascular injury. In this study, a complex hemodynamic assessment was performed by using TCD, SPECT and NIRS [52]. It was observed that an increase of regional CBF during SCS was measured in the surrounding stroke areas in half of the patients. According to the previous experiences of Mazzone et al. [19, 20], the evidence of redistribution of CBF rather than a clear increase was shown in such patients. More recently, De 
Table 3. Clinical studies on cerebral ischemia, vasospasm and tumor perfusion in humans

\begin{tabular}{|c|c|c|c|c|c|}
\hline $\begin{array}{l}\text { Reference } \\
\text { (first author) }\end{array}$ & Patients & $\mathrm{n}$ & $\begin{array}{l}\text { Stimulating } \\
\text { electrode site }\end{array}$ & Effect recording & Observation \\
\hline $\begin{array}{l}\text { Kanno } \\
1989[48]\end{array}$ & $\begin{array}{l}\text { patients with impaired } \\
\text { consciousness } \\
\text { (persistent vegetative } \\
\text { states) }\end{array}$ & 23 & cervical & SPECT & $\begin{array}{l}\text { clinical improvement in } 34 \% \\
\text { of patients; increase of the } \\
\text { metabolism of catecholamines } \\
\text { in CSF, NE, DA, DOPAC, } \\
\text { HVA, and 5-HIAA; increase } \\
\text { in regional CBF }\end{array}$ \\
\hline $\begin{array}{l}\text { Matsui } \\
1989[34]\end{array}$ & $\begin{array}{l}\text { patients with impaired } \\
\text { consciousness } \\
\text { (persistent vegetative } \\
\text { states) }\end{array}$ & 8 & cervical & SPECT & $\begin{array}{l}\text { clinical improvement (no } \\
\text { correlation of clinical outcome } \\
\text { with SPECT CBF investigation) }\end{array}$ \\
\hline $\begin{array}{l}\text { Hosobuchi } \\
1991 \text { [50] }\end{array}$ & cerebral ischemia & 3 & cervical & SPECT & increase in $\mathrm{CBF}$ \\
\hline $\begin{array}{l}\text { Visocchi } \\
1994[51]\end{array}$ & cerebral ischemia & 1 & cervical & $\begin{array}{l}\text { NIRS; surface poly- } \\
\text { electromyography; TCD }\end{array}$ & $\begin{array}{l}\text { clinical-neurophysiological } \\
\text { improvement }\end{array}$ \\
\hline $\begin{array}{l}\text { Broseta } \\
1994[36]\end{array}$ & $\begin{array}{l}\text { cerebral low-perfusion } \\
\text { syndrome }\end{array}$ & 10 & cervical & SPECT & $\begin{array}{l}\text { clinical improvement, no MRI } \\
\text { changes; increase in CBF }\end{array}$ \\
\hline $\begin{array}{l}\text { Takanashi } \\
2000[55]\end{array}$ & $\begin{array}{l}\text { cerebral vasospasm } \\
\text { (SAH patients; Hunt- } \\
\text { Hess 2-3, Fisher } 3 \text { ) }\end{array}$ & 10 & cervical & $\begin{array}{l}\text { xenon computed } \\
\text { tomography and cerebral } \\
\text { angiography }\end{array}$ & $\begin{array}{l}\text { increase in } \mathrm{CBF} \text {, clinical } \\
\text { improvement }\end{array}$ \\
\hline $\begin{array}{l}\text { Visocchi } \\
2001[52]\end{array}$ & $\begin{array}{l}\text { ischemic/hemorrhagic } \\
\text { brain damage }\end{array}$ & 18 & cervical & TCD; NIRS; SPECT & $\begin{array}{l}\text { clinical improvement, no } \\
\text { absolute correlation increase, } \\
\text { reduction, no changes in CBF }\end{array}$ \\
\hline $\begin{array}{l}\text { Clavo } \\
2007,2004,2003, \\
2002[56-59]\end{array}$ & $\begin{array}{l}\text { brain tumor perfusion } \\
\text { (advanced gliomas and } \\
\text { head and neck tumors) }\end{array}$ & 64 & cervical & $\begin{array}{l}\text { TCD, polarographic } \\
\text { probes }\end{array}$ & $\begin{array}{l}\text { increased tumor blood flow } \\
\text { and oxygenation }\end{array}$ \\
\hline $\begin{array}{l}\text { De Andrés } \\
2007[53]\end{array}$ & ischemic brain damage & 1 & cervical & Doppler, functional MRI & $\begin{array}{l}\text { clinical improvement, increase } \\
\text { in } \mathrm{CBF}\end{array}$ \\
\hline $\begin{array}{l}\text { Liu } \\
2008[54]\end{array}$ & $\begin{array}{l}\text { patients with impaired } \\
\text { consciousness } \\
\text { (persistent vegetative } \\
\text { states) }\end{array}$ & 20 & cervical & SPECT & $\begin{array}{l}\text { clinical improvement, increase } \\
\text { in CBF; increase in DA and NE } \\
\text { in CSF }\end{array}$ \\
\hline
\end{tabular}

5-HIAA = 5-Hydroxyindole acetic acid; DA = dopamine; DOPAC = 3,4-dihydroxyphenylacetic acid; HVA = homovanillic acid; $\mathrm{NE}=$ norepinephrine.

Andrés et al. [53] published a case harboring both severe cerebral ischemia and upper extremity ischemic pain, successfully treated with cervical SCS. A large series has recently been published by Liu et al. [54] who observed an increase of cerebral blood perfusion and catecholamine in CSF after SCS, suggesting that SCS increases cerebral blood perfusion, attenuates oxidative stress and increases biogenic amines in comatose patients.

Takanashi and Shinonaga [55] in 2000 published the only article found in the literature which is related to the use of SCS for cerebral vasospasm in humans. Ten SAH patients with secured cerebral aneurysm (ranging from Hunt-Hess grade 2-4, Fisher grade 3) were implanted with percutaneous epidural cervical leads. The stimulation was continuous and started on day 5 post-bleeding for 10-15 days in addition to standard medical treatment. They observed a significant increase of CBF in the MCA territory. Four of 10 patients showed angiographic vasospasm, but none developed severe clinical sequelae. The overall outcome was good or excellent in 7 of the $10 \mathrm{pa}$ - 
tients. The data analysis correlated with an increase in CBF with SCS. No major adverse effect was attributed to the use of SCS. The main limitations of this pivotal paper were the small sample size and significant impairment of neurological status of the patients on admission (HuntHess 3 or 4), thereby confusing the differentiation between morbidity and mortality from the hemorrhage itself versus that of the vasospasm. Even if no clinical judgment could be made, the paper constitutes the first attempt to evaluate SCS as an adjunctive therapy for cerebral vasospasm following SAH.

Finally, in 2009, Goellner and Slavin [4] suggested SCS at the $\mathrm{C} 6-\mathrm{C} 7$ level to 'prevent' vasospasm (inhibition of superior cervical ganglion) and at $\mathrm{C} 3-\mathrm{C} 4$ in order to 'treat' vasospasm (stimulation of brainstem reticular formation).

Clavo and colleagues [56-60] explored a potential novel application of SCS, investigating the effects of cervical SCS on CBF in patients with high-grade gliomas and head and neck tumors. These malignancies have a decreased locoregional blood flow resulting in reduced delivery of chemotherapy and oxygen, as well as an increase in radiation resistance to radiotherapy, and represent an important adverse prognostic factor. Clavo's results on a large series of patients suggest that neurostimulation can enhance the locoregional blood flow, thus ameliorating the delivery of oxygen, radiosensitizing and chemotherapeutic drugs. These findings have to be considered still preliminary and deserve further investigation; this technique could be a tool in modifying locoregional perfusion in brain tumors, thus improving the outcomes after radiochemotherapy [59, 60].

These observations suggest that in the future, SCS might represent a promising therapeutic tool in patients with stroke, cerebral vasospasm or even as an adjuvant to radiotherapy and chemotherapy regimens.

\section{The Future}

Although angina and peripheral vascular diseases are well-recognized indications for SCS, cerebral revascularization needs more evidence-based studies. Data concerning an increase in local or global CBF in stroke and in low-perfusion syndrome patients during SCS are published, but there is still no clear indication for SCS in such a clinical setting. Most of the studies performed so far have not achieved any clinical relevance.

There is clear evidence that SCS, particularly at the cervical level, affects CBF, but further studies are needed. Although all these results are quite exciting, there are still too many questions to be answered before such observations can be extended to the clinical practice (i.e. the exact positioning of the electrodes, the exact substrate to stimulate, the optimal stimulation parameters, etc.). The literature as well as personal observations seem to suggest a 'preventing or protecting' rather than 'therapeutic' effect of SCS on cerebrovascular disease models in animals, as demonstrated for cerebral edema, stroke and vasospasm. The newer publications on cerebral vasospasm and neuroprotective studies were either not relevant for clinical practice (SCS in acute vasospasm seems to be the most expensive, very invasive and least reliable way to maintain CBF) or failed to demonstrate any useful effect; very intriguing on this topic seems to be the recent paper published by Goellner and Slavin [4], theorizing on different cervical stimulation sites for prevention or treatment of cerebral vasospasm.

Both experimental and clinical studies are required in order to confirm a 'protective' effect of SCS on the chronic phase of cerebral vasospasm in humans and to investigate the 'therapeutic' rather than 'protective' effect of SCS on cerebrovascular diseases.

Possible therapeutic perspectives in the future will deal with the observations that SCS can modify locoregional blood flow in high-grade malignant tumors in the brain. Very preliminary data indicate that SCS might also find a place in neuro-oncology as an adjuvant treatment to standard radiochemotherapy $[59,60]$.

Finally, hemodynamic changes due to SCS seem to offer a new way to explain functional neurosurgery of pain. In 2006, Nagamachi et al. [61] concluded that chronic pain patients demonstrated abnormal regional CBF distribution on both baseline and post-SCS conditions. An increase in $\mathrm{CBF}$ in the thalamus under both conditions in chronic pain patients and a decrease in CBF under post-SCS conditions in successfully treated subjects raises attention to the possible new role of $\mathrm{CBF}$ studies providing important information on the selection of SCS candidates.

In conclusion, new perspectives in challenging neurosurgical clinical fields such as cerebral ischemia and vasospasm are called for $[62,63]$. In particular, the role of a 'functional' revascularization in chronic ischemic stroke in high-risk patients and in the elderly, along with a 'hemodynamic-enhancing-surgery salvage strategy' in severe vasospastic patients harboring $\mathrm{SAH}$, seems promising as a new trend of functional neurosurgery in cerebrovascular diseases. 


\section{References}

1 Visocchi M: Spinal cord stimulation and cerebral haemodynamics. Acta Neurochir Suppl 2006;99:111-116.

-2 De Vries J, De Jongste MJ, Spincemaille G, Staal MJ: Spinal cord stimulation for ischemic heart disease and peripheral vascular disease. Adv Tech Stand Neurosurg 2007;32: 63-89.

-3 Augustinsson LE, Eliasson T, Mannheimer C: Spinal cord stimulation in severe angina pectoris. Stereotact Funct Neurosurg 1995; 65:136-141.

-4 Goellner E, Slavin KV: Cervical spinal cord stimulation may prevent cerebral vasospasm by modulating sympathetic activity of the superior cervical ganglion at lower cervical spinal level. Med Hypotheses 2009;73:410413.

5 Robaina F, Clavo B: Spinal cord stimulation in the treatment of post-stroke patients: current state and future directions. Acta Neurochir Suppl 2007;97:277-282.

6 Reis DJ: Central Neural Control of Cerebral Circulation and Metabolism. New York, Raven Press, 1984, vol 2, pp 91-119.

7 Garcia-March G, Sanchez-Ledesna MJ, Broseta J: Effect of high cervical spinal cord stimulation on carotid and cerebral blood flow. An experimental study. Proc 8th European Congress of Neurosurgery, Barcelona 1987, p 106.

-8 Visocchi M, Cioni B, Vergari S, Marano G, Pentimalli L, Meglio M: Spinal cord stimulation and cerebral blood flow: an experimental study. Stereotact Funct Neurosurg 1994; 62:186-190.

\9 Garcia-March G, Sánchez-Ledesma MJ, Anaya J, Broseta J: Cerebral and carotid haemodynamic changes following cervical spinal cord stimulation. An experimental study. Acta Neurochir Suppl (Wien) 1989;46:102104.

10 Isono M, Kaga A, Fujiki M, Mori T, Hori S: Effect of spinal cord stimulation on cerebral blood flow in cats. Stereotact Funct Neurosurg 1995;64:40-46.

11 Sagher O, Huang DL: Effects of the cervical spinal cord stimulation on cerebral blood flow in the rat. J Neurosurg 2000;93:71-76.

12 Zhong J, Huang DL, Sagher O: Parameters influencing augmentation of cerebral blood flow by cervical spinal cord stimulation. Acta Neurochir (Wien) 2004;146:1227-1234

13 Hosobuchi Y: Electrical stimulation of the cervical spinal cord increases cerebral blood flow in humans. Appl Neurophysiol 1985;48: 372-376.

- 14 Aaslid R, Markwalder TM, Nornes H: Noninvasive transcranial Doppler ultrasound recording of flow velocity in basal cerebral arteries. J Neurosurg 1982;57:769-774

- 15 Linderoth B, Gherardini G, Ren BB, Lundeberg T: Preemptive spinal cord stimulation reduces ischemia in an animal model of vasospasm. Neurosurgery 1995;37:266-271.
16 Linderoth B, Gunasekera L, Meyerson BA: Effects of sympathectomy on skin and muscle microcirculation during dorsal column stimulation. Neurosurgery 1991;29:874-879.

17 Meglio M, Cioni B, Visocchi M: Cerebral haemodynamics during spinal cord stimulation. PACE 1991;14:127-130.

18 Meglio M, Cioni B, Visocchi M, Nobili F, Rodriguez G, Rosadini G, Chiappini F, Sandric S: Spinal cord stimulation and cerebral haemodynamics. Acta Neurochir (Wien) 1991; 111:43-48.

19 Mazzone P, Pisani R, Nobili F, Arrigo A, Rosadini G: Assessment of regional cerebral blood flow during spinal cord stimulation in humans. Stereotact Funct Neurosurg 1995; 64:197-201.

20 Mazzone P, Rodriguez G, Arrigo A, Nobili F, Rosadini G: Cerebral haemodynamic changes induced by spinal cord stimulation in man. Ital J Neurol Sci 1996;17:55-57.

-21 Ter Laan M, van Dijk JM, Elting JW, Fidler V, Staal MJ: The influence of transcutaneous electrical neurostimulation (TENS) on human cerebral blood flow velocities. Acta Neurochir (Wien) 2010;152:1367-1373.

22 Meglio M, Cioni B, Dal Lago A, De Santis M, Pola P, Serricchio M: Pain control and improvement of peripheral blood flow following epidural spinal cord stimulation. Case report. J Neurosurg 1981;54:821-823.

23 Meglio M, Cioni B, Rossi GF, Sandric S, Santarelli P: Spinal cord stimulation affects the central mechanisms of regulation of heart rate. Appl Neurophysiol 1986;49:139-146.

24 Visocchi M, Chiappini F, Cioni B, Meglio M: Cerebral blood flow velocities and trigeminal ganglion stimulation - a transcranial Doppler study. Stereotact Funct Neurosurg 1996;66:184-192.

25 Myklebust JB, Cusick JF, Boerboom LE, Prieto TE, Khan TA: Vascular effects of spinal cord stimulation in the monkey. Stereotact Funct Neurosurg 1995;64:32-39.

26 Patel S, Huang DL, Sagher O: Sympathetic mechanisms in cerebral blood flow alterations induced by spinal cord stimulation. J Neurosurg 2003;99:754-761.

27 Patel S, Huang DL, Sagher O: Evidence for a central pathway in the cerebrovascular effects of spinal cord stimulation. Neurosurgery 2004,55:201-206.

28 Linderoth B, Gherardini G, Ren B, Lundeberg T: Severe peripheral ischemia after vasospasm may be prevented by spinal cord stimulation. A preliminary report of study in a free-flap animal model. Acta Neurochir Suppl 1995;64:101-105.

29 Wu M, Komori N, Qin C, Farber JP, Linderoth B, Foreman RD: Roles of peripheral terminals of transient receptor potential vanilloid-1 containing sensory fibers in spinal cord stimulation-induced peripheral vasodilation. Brain Res 2007;1156:80-92.
30 Yang X, Farber JP, Wu M, Foreman RD, Qin $\mathrm{C}$ : Roles of dorsal column pathway and transient receptor potential vanilloid type 1 in augmentation of cerebral blood flow by upper cervical spinal cord stimulation in rats. Neuroscience 2008;152:950-958.

-31 Wu M, Komori N, Qin C, Farber JP, Linderoth B, Foreman RD: Extracellular signalregulated kinase and protein kinase $B$ pathways involved in spinal cord stimulation-induced vasodilation. Brain Res 2008;1207: 73-83.

32 Visocchi M, Bucci MG, Cioni B, Manni G, Meglio M, Puca A, Quaranta L: Cerebral and ophthalmic haemodynamics during SCS. I International INS Congress Rome, 1992. Bologna, Monduzzi, 1992, pp 137-143.

33 Visocchi M, Cioni B, Meglio M: Spinal cord stimulation impairs cerebral autoregulation. Acta Med Rom 1996;28:173-178.

34 Matsui T, Hosobuchi Y: The effects of cervical spinal cord stimulation on experimental stroke. PACE 1989;12:726-732.

- 35 Gonzalez-Darder J, Canadas-Rodriguez D: Effects of cervical spinal cord stimulation in experimental ischemic oedema. Neurol Res 1991;13:229-232.

- 36 Broseta J, Garcia-Mark G, Sancez-Ledesma MJ, Goncalves J: High cervical spinal cord electrical stimulation in brain low-perfusion syndromes: experimental basis and preliminary clinical report. Stereotact Funct Neurosurg 1994;62:171-178.

37 Sagher O, Huang DL, Keep RF: Spinal cord stimulation reducing infarct volume in a model of focal cerebral ischemia in rats. J Neurosurg 2003;99:131-137.

- 38 Visocchi M, Argiolas L, Meglio M, Cioni B, Dal Basso P, Rollo M, Cabezas Cuevas D: Spinal cord stimulation and early experimental cerebral spasm: the functional monitoring and the preventing effect. Acta Neurochir (Wien) 2001;143:177-185.

- 39 Treggiari MM, Romand JA, Martin JB, Reverdin A, Rüfenacht DA, de Tribolet N: Cervical sympathetic block to reverse delayed ischemic neurological deficits after aneurysmal subarachnoid hemorrhage. Stroke 2003;34:961-967.

-40 Naredi S, Lambert G, Edén E, Zäll S, Runnerstam M, Rydenhag B, Friberg P: Increased sympathetic nervous activity in patients with nontraumatic subarachnoid hemorrhage. Stroke 2000;31:901-906.

-41 Visocchi M: Neuromodulation of cerebral blood flow by spinal cord electrical stimulation: the role of the Italian school and state of art. J Neurosurg Sci 2008;52:41-47.

42 Visocchi M, Meglio M, Argiolas L, Pentimalli L, Cioni B: Spinal cord stimulation prevents cerebral early vasospasm. An experimental study. III INS Congress, Orlando, March 6-10, 1996, pp 56-57. 
43 Visocchi M, Tartaglione T, Romani R, Meglio M: Spinal cord stimulation prevents the effects of combined ischemic and traumatic brain injury. An MR study. Stereotact Funct Neurosurg 2001;76:276-281.

44 Ebel H, Semmelmann G, Schomaker K, Ba$\operatorname{logh}$ A, Volz M, Funke J, Schicha H, Klug N: Effects of high cervical SCS on regional CBF after induced SAH in rats. Acta Neurochir Suppl 2001;77:225-227.

-45 Ebel H, Semmelmann G, Schomaker K, Ba$\operatorname{logh}$ A, Volz M, Funke J, Schicha H, Klug N: High cervical SCS increases regional CBF after induced $\mathrm{SAH}$ in rats. Minim Invasive Neurosurg 2001;44:167-171.

-46 Gurelik M, Kayabas M, Karadag O, Goksel HM, Akyuz A, Topaktas S: Cervical SCS improves neurological dysfunction induced by cerebral vasospasm. Neuroscience 2005; 134 : 837-832.

-47 Karadag O, Eroglu E, Gurelik M, Goksel HM, Kilic E, Gulturk S: Cervical SCS increases cerebral cortical BF in an experimental cerebral vasospasm model. Acta Neurochir (Wien) 2005;147:79-84.

48 Kanno T, Yoshifumi K, Yokoyama T, Shoda M, Tanji H, Nomura M: Effects of dorsal column spinal cord stimulation on reversibility of neuronal function. Experience of treatment for vegetative states. PACE 1989;12: 733-742.

49 Matsui T, Asano T, Takakura K, Yamada R, Hosobuchi Y: Beneficial effects of cervical spinal cord stimulation on patients with impaired consciousness: a preliminary report: PACE 1989;12:718-725.

50 Hosobuchi Y: Treatment of cerebral ischemia with electrical stimulation of the cervical spinal cord. PACE 1991;14:122-126.
51 Visocchi M, Cioni B, Pentimalli L, Meglio M: Increase of cerebral blood flow and improvement of brain motor control following spinal cord stimulation in ischemic spastic hemiparesis. Stereotact Funct Neurosurg 1994;62: 103-107.

52 Visocchi M, Giordano A, Calcagni M, Cioni B, Di Rocco C, Meglio M: Spinal cord stimulation and cerebral blood flow in stroke: personal experience. Stereotact Funct Neurosurg 2001;76:262-268.

53 De Andrés J, Tatay J, Revert A, Valía JC, Villanueva $\mathrm{V}$ : The beneficial effect of spinal cord stimulation in a patient with severe cerebral ischemia and upper extremity ischemic pain. Pain Pract 2007;7:135-142.

54 Liu JT, Tan WC, Liao WJ: Effects of electrical cervical spinal cord stimulation on cerebral blood perfusion, cerebrospinal fluid catecholamine levels, and oxidative stress in comatose patients. Acta Neurochir Suppl 2008; 101:71-76.

55 Takanashi Y, Shinonaga M: Spinal cord stimulation for cerebral vasospasm as prophylaxis. Neurol Med Chir (Tokyo) 2000;40:352356.

56 Clavo B, Robaina F, Catalá L, Lloret M, Pinar B, Caramés MA, Ruiz A, Cabezón A, González G, Lara P, Ruiz-Egea E, Hernández MA: Cerebral blood flow increase in cancer patients by applying cervical spinal cord stimulation. Neurocirugia (Astur) 2007;18: 28-32.

57 Clavo B, Robaina F, Catalá L, Pérez JL, Lloret M, Caramés MA, Morera J, López L, Suárez G, Macías D, Rivero J, Hernández MA: Effect of cervical spinal cord stimulation on regional blood flow and oxygenation in advanced head and neck tumours. Ann Oncol 2004; 15:802-807.
58 Clavo B, Robaina F, Catala L, Valcarcel B, Morea J, Carames MA, Ruiz-Egea E, Paneo F, Lloret M, Hernandez MA: Increase locoregional $\mathrm{BF}$ in brain tumors after Cervical SCS. J Neurosurg 2003;98:1263-1270.

59 Clavo B, Robaina F, Morera J, Ruiz-Egea E, Pérez JL, Macías D, Caramés MA, Catalá L, Hernández MA, Günderoth M: Increase of brain tumor oxygenation during cervical spinal cord stimulation. Report of three cases. J Neurosurg 2002;96:94-100.

60 Robaina F, Clavo B: The role of spinal cord stimulation in the management of patients with brain tumors. Acta Neurochir Suppl 2007;97:445-543.

61 Nagamachi S, Fujita S, Nishii R, Futami S, Wakamatsu H, Yano T, Kodama T, Tamura S, Kunitake A, Uno T, Takasaki M: Alteration of regional cerebral blood flow in patients with chronic pain - evaluation before and after epidural spinal cord stimulation. Ann Nucl Med 2006;20:303-310.

62 Sagher O: Effects of spinal cord stimulation on cerebrovascular flow: role of sympathetic and parasympathetic innervations. Neurosci Bull 2006;22:261-266.

63 Upadhyaya CD, Sagher O: Cervical spinal cord stimulation in cerebral ischemia. Acta Neurochir Suppl 2007;97:267-275.

64 Visocchi M, Di Rocco C, Meglio M: Protective effect of spinal cord stimulation on experimental early cerebral vasospasm. Conclusive results. Stereotact Funct Neurosurg 2001;76:269-275

65 Lee JY, Huang DL, Keep R, Sagher O: Effect of electrical stimulation of the cervical spinal cord on blood flow following subarachnoid hemorrhage. J Neurosurg 2008;109:11481154 . 